\title{
Productivity of new sugarcane hybrids in the Lajas Valley and their resistance to smut and rust'
}

\author{
Rodrigo Echavez-Badel ${ }^{2}$
}

\begin{abstract}
Seventeen promising new sugarcane hybrids and three check varieties were planted in the Lajas valley, a semi-arid and irrigated area of southwestern Puerto Rico. Plant cane and ratoon crops were evaluated for yield and resistance to smut (Ustilago scitaminea Syd.) and rust (Puccinia melanocephala H. Syd. \& P. Syd.). All new hybrids tested were resistant and tolerant to smut and rust. The smut incidence on susceptible check increased after ratooning. However, rust resistance and susceptibility of sugareane hybrids and check varieties remained unchanged throughout a three-crop cycle. Combined analysis of variance of 2 years (plant and first ratoon crops) indicated that yields (sugar ton/ha) of five hybrids were consistently higher than those of the other genotypes tested, including the standard check varieły PR 980.
\end{abstract}

\section{RESUMEN}

Productividad de nuevos híbridos de caña de azúcar en el valle de Lajas y su resistencia al carbón y a la roya

En el valle semiárido de Lajas, en el suroeste de Puerto Rico, se sembraron con riega 17 nuevos híbridos de caña de azúcar para evaluar su rendimiento y resistencia al carbón (Ustilago scitaminea Syd.) y a la roya (Puccinia melanocephala H. Syd. \& P. Syd.) en las etapas de plantilla y retoños. Todos los nuevos híbridos mostraron resistencia y tolerancia a estas enfermedades. La incidencia del carbón aumentó en el testigo susceptible cuando se dejó retoñar; sin embargo, la resistencia y susceptibilidad de los híbridos y variedades testigo a la roya se mantuvieron inalteradas durante los 3 años de siembra. El análisis de varianza combinado de 2 años (plantilla y primer retoño) indicó que la producción de 5 híbridos fue consistente y más alta que la de los demás genotipos, incluyendo la variedad testigo PR 980.

\section{INTRODUCTION}

Sugarcane production in Puerto Rico has declined drastically in the last 20 years from almost $6,000,000$ tons in 1969 to $1,216,000$ tons in 1989 ,

'Manuscript submitted to Editorial Board 13 December 1990.

${ }^{2}$ Assistant Plant Pathologist, Department of Crop Protection. The author thanks the sugarcane breeding program personnel at Lajas, Isabela, Juana Díaz and Gurabo substations for sugarcane hybrids and also Santos A. Henriquez at the Lajas Substation for technical help. He also thanks the Central Analytical Laboratory and the Statistics Section of the Agricultural Experiment Station at Rio Piedras for processing sugarcane samples and analyzing data, respectively. 
an $80 \%$ reduction. However, in economic importance sugarcane is the third crop after coffee and plantain in the island. In 1989 it contributed about $\$ 25$ million to our gross income $(1,9)$.

Acreage of cane harvested is estimated at 20,000 ha. Yield is about 61 tons per ha. The smut-susceptible variety PR980 occupies $22 \%$ of the sugarcane acreage in Puerto Rico. Fortunately, it has been gradually replaced by new varieties highly resistant to smut and rust, with good yield and performance in south and southeastern Puerto Rico.

Among 85 sugarcane diseases reported in the world (8), smut (Ustilago scitaminea Syd.) and rust (Puccinia melanocephala H. Syd. \& P. Syd.) are now widely distributed in Puerto Rico $(5,6)$. A factor for the rapid dissemination of both diseases has been the use of susceptible varieties. A group of promising sugarcane hybrids of the AES-UPR cane breeding program have been tested in different ecological and sugarcane producing areas in the island with good performance in plant cane and ratoon crops. The objective of the research was to evaluate 17 hybrids for productivity and resistance to smut and rust in a semi-arid and irrigated area of Puerto Rico.

\section{MATERIALS AND METHODS}

Field tests were conducted at the Lajas Substation in southwestern Puerto Rico from April 1987 to January 1990. The soil is a Vertisol with a $\mathrm{pH}$ of 7.3. Seventeen promising sugarcane hybrids from the AES-UPR cane breeding program and three check varieties were planted in four replicated field plots. A partially balanced incomplete block design was used. Plot size consisted of 4 rows $1.52 \mathrm{~m}$ apart and $3.05 \mathrm{~m}$ long.

Smut- and rust-susceptible varieties PR 80-1052 and PR 67-3129 were used. PR 980 was the standard check. Hybrids and checks were monitored for smut and rust symptoms during the course of plant cane and two ratoon crops. The scales used for smut monitoring in Hawaii (10) and for rust in Florida (12) were modified slightly for the present evaluations. In both numerical scales, the values 0 to 1 denote highest resistance, and the value 9 denotes highest susceptibility. Hybrids and checks were rated at tillering ( 4 to 5 months of age) and at pre-maturity stages of growth (8-10 months of age). Rust severity was observed basipetally from the top visible dewlap (TVD) leaf (7). An analysis of variance was performed for data on cane tonnage, sugar content, and sugar yields per ha for each test. A combined analysis of variance for plant and first ratoon crops was also made. Planting, irrigation, cultivation, fertilization, and weeding followed the general practice of this area.

\section{RESULTS AND DISCUSSION}

Table 1 shows data on sucrose content, tons of cane, and tons of sugar per ha for the plant cane crop. As to total sugar of the plant cane crop 
TABLE 1.-Plant cane crop mean yields of the 17 best performing sugarcane hybrids and checks at the Lajas Substation

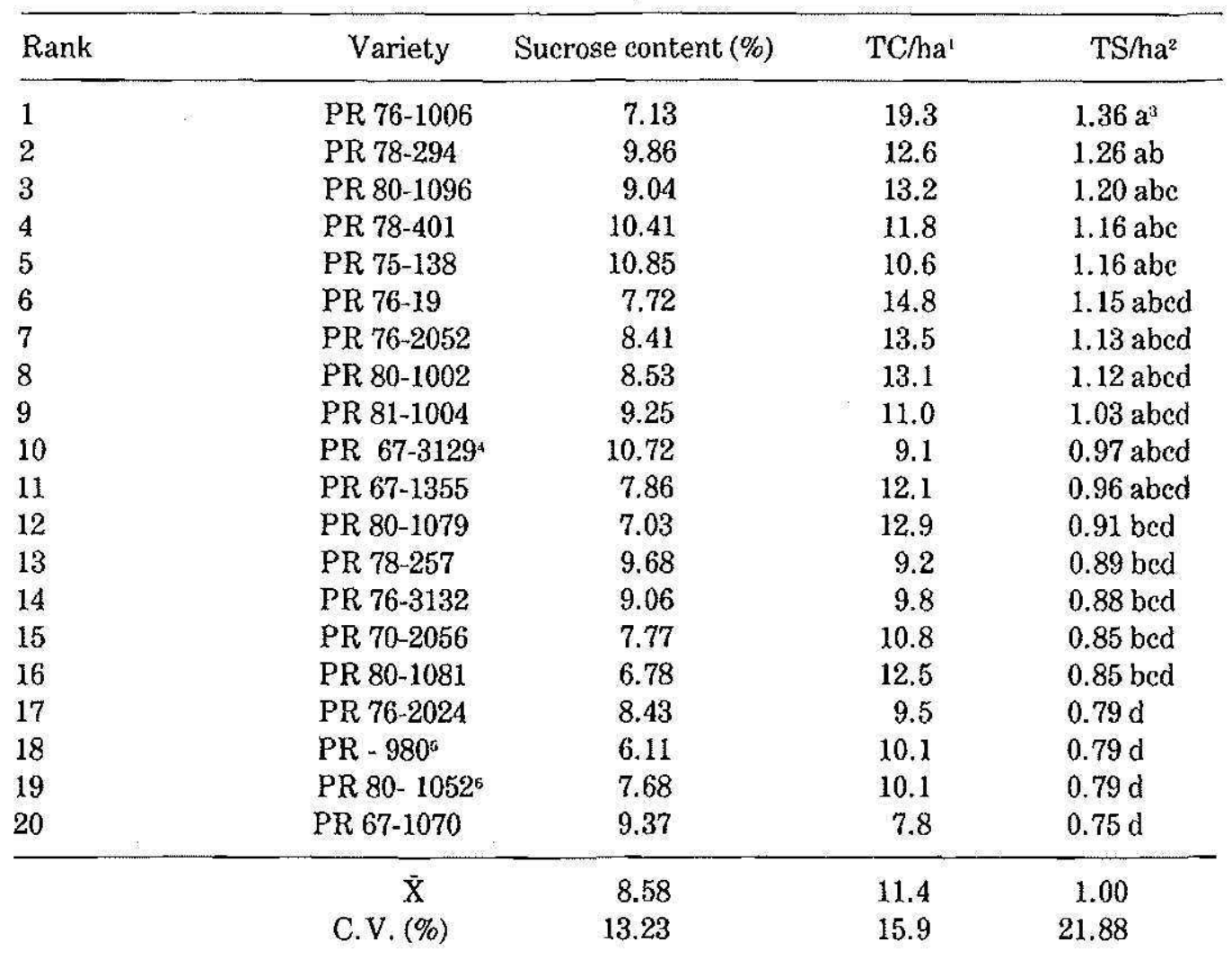

'Tons of cane per ha.

2Tons of sugar per ha.

"Values in column followed by the same letter do not differ significantly at the $5 \%$ probability level.

${ }^{4}$ Rust susceptible check.

${ }^{5}$ Standard check.

${ }^{6}$ Smut susceptible check.

calculated on the basis of sucrose content and tonnage of cane, PR 761006 was the leading hybrid followed by the other 10 genotypes, including the rust susceptible check PR 67-3129 and PR 67-1355, but there were no significant differences among them (table 1). Results from the first ratoon crop (table 2) indicate that tonnage of cane (18.9 vs 11.4) and sugar (1.95 vs 1.00) per ha were higher than those obtained in plant eane. The percentage of sucrose was also higher (10.2 vs 8.6). Presumably, yields were affected by prolonged rainfall during the plant cane harvest ( $83 \mathrm{~mm}$ vs $14 \mathrm{~mm}$ in the first ratoon harvest). No significant differences were observed in tons of sugar per ha among the first 15 genotypes. However, the yields of PR-1006, PR 78-294, and PR 75-138 were higher than those of the standard check PR 980. In spite of the fact that the sucrose content of PR 76-1006 was lower than that of the mean value of the first ratoon test $(9.9$ vs 10.2$)$, the tonnage of cane per ha and con- 
TABLE 2.-Frist ratoon crop mean yields of the 17 best performing sugarcane hybrids and checks at the Lajas Substation

\begin{tabular}{llrrr}
\hline Rank & Variety & Sucrose content (\%) & TC/ha & TS/ha \\
\hline 1 & PR 76-1006 & 9.90 & 28.9 & $2.90 \mathrm{a}^{3}$ \\
2 & PR 78-294 & 12.58 & 21.2 & $2.81 \mathrm{a}$ \\
3 & PR 75-138 & 9954 & 25.1 & $2.51 \mathrm{ab}$ \\
4 & PR - 980 & 9.77 & 25.3 & $2.47 \mathrm{abc}$ \\
5 & PR 78-401 & 10.72 & 20.2 & $2.16 \mathrm{abcd}$ \\
6 & PR 80-1096 & 11.79 & 18.2 & $2.15 \mathrm{abcd}$ \\
7 & PR 80-1081 & 10.40 & 20.3 & $2.14 \mathrm{abcd}$ \\
8 & PR 67-1355 & 11.13 & 20.6 & $2.10 \mathrm{abcd}$ \\
9 & PR 81-1004 & 9.94 & 20.0 & $2.04 \mathrm{abcd}$ \\
10 & PR 76-19 & 9.31 & 22.6 & $2.02 \mathrm{abcd}$ \\
11 & PR 78-257 & 9.26 & 20.0 & $1.97 \mathrm{abcd}$ \\
12 & PR 80-1029 & 9.84 & 19.6 & $1.91 \mathrm{abcd}$ \\
13 & PR 78-2024 & 10.44 & 18.9 & $1.84 \mathrm{abcd}$ \\
14 & PR 70-2056 & 11.62 & 15.3 & $1.83 \mathrm{abcd}$ \\
15 & PR 67-31295 & 10.64 & 16.3 & $1.73 \mathrm{abcd}$ \\
16 & PR 80-1079 & 8.47 & 16.6 & $1.55 \mathrm{bcd}$ \\
17 & PR 76-3132 & 10.82 & 11.6 & $1.30 \mathrm{bcd}$ \\
18 & PR 76-2052 & 9.33 & 12.2 & $1.30 \mathrm{bcd}$ \\
19 & PR 80- 1052 & 7.42 & 15.5 & $1.27 \mathrm{~cd}$ \\
20 & PR 67-1070 & 10.74 & 9.9 & $1.04 \mathrm{~d}$ \\
\hline
\end{tabular}

'Tons of cane per ha.

${ }^{2}$ Tons of sugar per ha.

${ }^{3}$ Values in column followed by the same letter do not differ significantly at the 5\% probability level.

${ }^{4}$ Standard check.

${ }^{5}$ Rust susceptible check check.

${ }^{6}$ Smut susceptible check.

sequently the tons of sugar per ha were the highest among the 20 genotypes tested (table 2).

The combined analysis of variance from plant cane and first ratoon crops indicates that PR 76-1006, PR 78-294, PR 75-138, PR 80-1096, and PR 78-401 continue to be consistently good yielders (table 3 ). The sweet hybrid PR 67-1070 produced the lowest yields (tonnages of cane and sugar) among the 20 genotypes tested. It appears that this hybrid could not adapt well in the heavy soils with the poor drainage conditions of the Lajas valley. Chu and Rodriguez (3) reported that PR 67-1070 was better adapted to humid or irrigated areas in light soils with good drainage. In spite of the fact that the acreage of the hybrid PR 67-1355 has been expanded in the last 5 years, its yields obtained in two cycles were lower than those of PR 980 (table 3). 
TABLE 3.-Plant cane and first ratoon mean yields of the 17 best performing sugarcane hybrids and checks at the Lajas Substation

\begin{tabular}{|c|c|c|c|c|}
\hline Rank & Variety & Sucrose content (\%) & TC/ha' & TS/ha ${ }^{2}$ \\
\hline 1 & PR 76-1006 & 8.50 & 24.1 & $2.13 \mathrm{a}^{3}$ \\
\hline 2 & PR 78-294 & 11.20 & 17.0 & $2.03 \mathrm{ab}$ \\
\hline 3 & PR 75-138 & 10.40 & 17.8 & $1.83 a b c$ \\
\hline 4 & PR 80-1096 & 10.43 & 15.7 & $1.69 \mathrm{abcd}$ \\
\hline 5 & PR 78-401 & 10.82 & 15.3 & $1.63 \mathrm{abed}$ \\
\hline 6 & $980^{4}$ & 7.94 & 19.5 & $1.63 \mathrm{abcd}$ \\
\hline 7 & PR 76-19 & 8.52 & 18.7 & 1.59 abcde \\
\hline 8 & PR 67-1355 & 9.48 & 16.4 & 1.53 abcde \\
\hline 9 & PR 81-1004 & 9.58 & 15.5 & 1.52 abcde \\
\hline 10 & PR 80-1002 & 9.47 & 16.3 & 1.49 abcde \\
\hline 11 & PR 80-1081 & 8.60 & 16.3 & 1.49 abcde \\
\hline 12 & PR 78-257 & 9.47 & 14.6 & 1.43 bcde \\
\hline 13 & PR 78-2024 & 9.18 & 14.9 & 1.36 bcde \\
\hline 14 & PR 67-3129 & 10.70 & 12.7 & 1.36 bede \\
\hline 15 & PR 70-2056 & 9.69 & 13.1 & 1.34 bcde \\
\hline 16 & PR 80-1079 & 7.75 & 14.7 & 1.23 cde \\
\hline 17 & PR 76-2052 & 8.88 & 12.8 & 1.21 ede \\
\hline 18 & PR 76-3132 & 9.93 & 10.6 & $1.08 \mathrm{de}$ \\
\hline 19 & PR $80-1052^{6}$ & 7.56 & 12.9 & $1.04 \mathrm{de}$ \\
\hline \multirow[t]{3}{*}{20} & PR 67-1070 & 10.05 & 8.9 & $0.89 \mathrm{e}$ \\
\hline & $\overline{\mathrm{X}}$ & 9.39 & 15.4 & 1.48 \\
\hline & C.V. (\%) & 9.50 & 22.7 & 25.22 \\
\hline
\end{tabular}

'Tons of cane per ha.

${ }^{2}$ Tons of sugar per ha.

${ }^{3}$ Values in column followed by the same letter do not differ significantly at the $5 \%$ probability level.

'Standard check.

'Rust susceptible check.

'Smut susceptible check.

Yield data reported in this paper indicate that new hybrids, which performed well in other ecological areas of Puerto Rico, are poor producers when grown under conditions prevailing in the Lajas valley regardless of adequate irrigation.

Rust disease incidence was similar to that observed in plant cane and first ratoon crop. Although rust and smut incidence was relatively lower throughout three tests, the rust and smut susceptible references revealed the highest infection during the cycle crops (table 4 ). The smut infection of PR 80-1002, PR 76-19, the smut check PR 80-1052, and the standard check PR 980 increased after ratooning (table 4). Similar results have been reported recently in Puerto Rico $(5,6)$. The smut infection did not change the sugar content of the smut susceptible check for PR-801052 (tables 1, 2). It has not been reported that smut is causing overall 
TABLE 4.-Reaction of 17 performing sugarcane hybrids and checks to smut (Ustilago scitaminea) and rust (Puccinia melanocephala) at the Lajas Substation

\begin{tabular}{|c|c|c|c|c|c|c|c|c|c|c|c|c|}
\hline \multirow[b]{3}{*}{ Variety } & \multicolumn{4}{|c|}{ Plant Cane } & \multicolumn{4}{|c|}{ First Ratoon } & \multicolumn{4}{|c|}{ Second Ratoon } \\
\hline & \multicolumn{2}{|c|}{ Smut' } & \multicolumn{2}{|c|}{ Rust $t^{*}$} & \multicolumn{2}{|c|}{ Smut } & \multicolumn{2}{|c|}{ Rust } & \multicolumn{2}{|c|}{ Smut } & \multicolumn{2}{|c|}{ Rust } \\
\hline & G & $\mathrm{Rn}$ & G & $R n$ & $\mathrm{G}$ & $R n$ & G & Rn & G & $\mathrm{Rn}$ & G & $\mathrm{Rn}$ \\
\hline PR 76-1006 & 1 & $\mathrm{R}$ & 0 & $\mathrm{R}$ & 1 & $\mathrm{R}$ & 0 & $\mathrm{R}$ & 1 & $\mathrm{R}$ & 0 & $\mathrm{R}$ \\
\hline PR 78-294 & 1 & $R$ & 0 & $\mathrm{R}$ & 1 & $\mathrm{R}$ & 0 & $\mathrm{R}$ & 1 & $\mathrm{R}$ & 0 & $\mathrm{R}$ \\
\hline PR 75-138 & 1 & $\mathrm{R}$ & 0 & $\mathrm{R}$ & 1 & $\mathrm{R}$ & 0 & $\mathrm{R}$ & 1 & $\mathrm{R}$ & 0 & $\mathrm{R}$ \\
\hline PR 78-1096 & 1 & $\mathrm{R}$ & 2 & $\mathrm{R}$ & 1 & $\mathrm{R}$ & 3 & $\mathrm{R}$ & 1 & $R$ & 0 & $\mathrm{R}$ \\
\hline PR 78-401 & 1 & $\mathrm{R}$ & 0 & $\mathrm{~K}$ & 2 & $\mathrm{~T}$ & 0 & $\mathrm{R}$ & 2 & $\mathrm{~T}$ & 0 & $\mathrm{R}$ \\
\hline PR $980^{3}$ & 4 & $\mathrm{~T}$ & 0 & $\mathrm{R}$ & 6 & $\mathrm{~S}$ & 0 & $\mathrm{R}$ & 4 & $\mathrm{~T}$ & 0 & $\mathrm{R}$ \\
\hline PR 76-19 & 1 & $\mathrm{R}$ & 1 & $\mathrm{R}$ & 2 & $\mathrm{~T}$ & 1 & $\mathrm{R}$ & 1 & $\mathrm{R}$ & 0 & $\mathrm{R}$ \\
\hline PR 67-1355 & 1 & $\mathrm{R}$ & 1 & $\mathrm{R}$ & 1 & $\mathrm{R}$ & 4 & $\mathrm{R}$ & 1 & $\mathrm{R}$ & 0 & $\mathrm{R}$ \\
\hline PR 81-1004 & 1 & $\mathrm{R}$ & $\mathrm{I}$ & $\mathrm{R}$ & 1 & $R$ & 5 & $\mathrm{~T}$ & 1 & $\mathrm{R}$ & 0 & $\mathrm{R}$ \\
\hline PR 80-1002 & 3 & $\mathrm{~T}$ & 0 & $\mathrm{R}$ & 3 & $\mathrm{~T}$ & 0 & $\mathrm{R}$ & 2 & $\mathrm{~T}$ & 0 & $\mathrm{R}$ \\
\hline PR 80-1081 & 1 & $R$ & 2 & $\mathrm{R}$ & 1 & $\mathrm{R}$ & 0 & $\mathrm{R}$ & 1 & $\mathrm{R}$ & 1 & $\mathrm{R}$ \\
\hline PR 78-257 & I & $\mathrm{R}$ & 0 & $\mathrm{R}$ & 1 & $\mathrm{R}$ & 2 & $\mathbf{R}$ & 1 & $\mathrm{R}$ & 0 & $\mathrm{R}$ \\
\hline PR 78-202A & 1 & $\mathrm{R}$ & 1 & $\mathrm{R}$ & 1 & $\mathrm{R}$ & 1 & $\mathrm{R}$ & 1 & $\mathrm{R}$ & 0 & $\mathrm{R}$ \\
\hline PR 67-31294 & 1 & $\mathrm{R}$ & 7 & $\mathrm{~S}$ & 1 & $\mathrm{R}$ & 8 & $S$ & 1 & $\mathrm{R}$ & 7 & $\mathrm{~S}$ \\
\hline PR 70-2056 & 1 & $\mathrm{R}$ & 0 & $\mathrm{R}$ & 1 & $\mathrm{R}$ & 0 & $\mathrm{R}$ & 1 & $R$ & 0 & $\mathrm{R}$ \\
\hline PR 80-1079 & 1 & $\mathrm{R}$ & 0 & $\mathrm{R}$ & 1 & $\mathrm{R}$ & 1 & $\mathrm{R}$ & 1 & $R$ & 0 & $R$ \\
\hline PR 76-2052 & 1 & $\mathrm{R}$ & 1 & $\mathrm{R}$ & 1 & $\mathrm{R}$ & 3 & $\mathrm{R}$ & 1 & $\mathrm{R}$ & 0 & $\mathrm{R}$ \\
\hline PR 76-3132 & 1 & $\mathrm{R}$ & 0 & $\mathrm{R}$ & 1 & $R$ & 0 & $\mathrm{R}$ & 1 & $\mathrm{R}$ & 0 & $\mathrm{R}$ \\
\hline PR 80-10525 & 6 & S & 0 & $\mathrm{R}$ & 8 & $\mathrm{~S}$ & 0 & $\mathrm{R}$ & 7 & S & 2 & $R$ \\
\hline PR 67-1070 & 1 & $\mathrm{R}$ & 0 & $\mathrm{R}$ & 1 & $\mathrm{R}$ & 0 & $\mathrm{R}$ & 1 & $\mathrm{R}$ & 0 & $\mathrm{R}$ \\
\hline$\overline{\mathrm{X}}$ & 1. & & 0.8 & & & 8 & 1. & 4 & 1. & 6 & 0 . & 5 \\
\hline
\end{tabular}

'Modified Hawaiian scale: Grade $(G) 1=$ Resistant (R) Reaction (Rn) 2-A=Tolerant (T); $5=$ Intermediate $(\mathrm{I})$ and $6 \cdot 9=$ Susceptible $(\mathrm{S})$.

${ }^{2}$ Modified Florida scale: Grade (G) 0-4Resistant (R) Reaction (Rn) $5=$ Intermediate (I) and $6-9=$ Susceptible $(\mathrm{S})$.

3 Standard check.

${ }^{4}$ Rust susceptible check.

${ }^{5}$ Smut sulsceptible check.

decline in sucrose content in susceptible varieties. However, the smut affected stalks become non millable cane because of corkiness, and are dwarfed with little or no juice content (2).

Sugarcane hybrids PR 67-1355 and PR 81-1004 had intermediate levels of resistance to rust (table 4). However, PR 67-1355 is susceptible to rust in the early stages of growth but becomes much more resistant thereafter. This mature-plant resistance phenomenon has been observed for Puerto Rico $(6,11)$ and Florida (4). The rust-susceptible check PR 67-3129 has remained susceptible throughout the cycle crops and still remained heavily infected at harvest. This finding indicates that there was uniformity of dispersal of inoculum over the area, but the intensity of rush infection was variable. 


\section{LITERATURE CITED}

1. Anuario de Estadísticas Agrícolas de Puerto Rico, 1985-86. Oficina de Estadísticas Agrícolas, Departamento de Agricultura, Estado Libre Asociado de Puerto Rico, Santurce, Puerto Rico.

2. Burgess, R. A., 1980. The effect of smut on sugarcane yields in Jamaica. Proceedings First Inter-American Sugar Cane Seminar. Cane Diseases, Florida International University, Miami, Florida. 4-5 p.

3. Chu, Teh-ling and J. L. Rodriguez, 1982. Sugarcane Breeding in Puerto Rico. Proceedings III Inter-American Sugar Cane Seminar. Varieties and Breeding. Florida International University, Miami, Florida.

4. Dean, J. L., 1980. Sugarcane Rust in Florida. Proceedings First Inter-American Sugar Cane Seminar. Cane Diseases. Florida International University, Maimi, Florida.

5. Echávez-Badel, R. and J. L. Rodriguez, 1986. Resistance of 43 sugarcane clones to smut (Ustilago scitaminea Sydow). J. Agric. Univ. P. R. 70 (4); 287-92.

6. - - - and C. E. Ortiz, 1989. Resistance to rust and smut among Puerto Rico sugarcane clones. J. Agric. Univ. P. R. 73 (1): 45-9.

7. FAO Manual on the evaluation and prevention of losses by pests, diseases and weeds, 1971. Crop loss assessment methods. Supplement. 4.4-6.1 p.

8. Hughes, C. G., 1978. Diseases of sugarcane-a review. Pest Articles News Sum. 24: 143-59.

9. Informe Anual de la Junta Azucarera, 1989. Junta Azucarera de Puerto Rico.

10. Ladd, S. L. and D. J. Heinz, 1976. Smut reaction of non-Hawaiian sugarcane clones. Sugarcane Pathol. Newsl. 17: 6-14.

11. Liu, L. J., 1980. Maturity resistance, a useful phenomenon for integrated control of sugarcane rust. Sugarcane Pathol. Newsl. 25: 11-3.

12. Purdy, L. H. and J. L. Dean, 1981. A system for recording data about sugarcane rest/host interactions. Sugarcane Pathol. Newsl. 27: 35-40. 